doi: 10.32620/oikit.2019.83.03

УДК 656.7

М. М. Орловський, А. В. Приймак,

Ю. Ю. Височанська, К. А. Гальчинський*

\title{
Дослідження стану льотної придатності та перспективи розвитку цивільного авіаційного парку України
}

\author{
Національний аерокосмічний університет ім. М.Є. Жуковського \\ «Харківський авіаційний інститут» \\ * Харківський національний університет Повітряних Сил ім.І.Кожедуба
}

\begin{abstract}
Проведене дослідження стану авіаційного парку України: показані тенденції зміни показників ефективності використання цивільної авіації України за період 2003-2018 рр, а також проаналізовано віковий та кількісний склад авіаційного парку провідних авіакомпаній, таких як авіакомпанія «Міжнародні авіалінії України» та ТОВ «Авіаційна компанія «Роза вітрів» та інших.

Визначено, що розвиток цивільної авіації пов'язаний із загальними тенденціями міжнародного повітряного транспорту і обумовлений як загальносвітовими, так і внутрішньодержавними соціально-економічними, політичними та іншими фракторами.

Встановлено, що питання надійності авіаційної техніки, стану безпеки польотів, які безпосередньо пов'язане із забезпеченням та підтримання льотної придатності повітряних суден $є$ та залишатимуться актуальними для усіх без винятку країн, не залежно від рівня розвитку та стану технологій, що використовуються для їх забезпечення.
\end{abstract}

Встановлено, що основними фракторами, які визначають актуальність питань підтримання та підтвердження льотної придатності цивільних повітряних суден $є$ : необхідність забезпечення безпечної експлуатації одночасно різних вікових груп авіаційної техніки та використання інтенсивно старіючої техніки вітчизняного виробництва; недостатня ефективність системи моніторингу за станом надійності та працездатності авіаційної техніки; неготовність існуючої системи експлуатації до ефективного функціонування в умовах масового вичерпання встановлених строків служби більшості об'єктів авіаційної техніки; катастрофрічно низький рівень фрінансування досліджень, пов'язаних з технічним супроводженням експлуатації авіаційної техніки; відсутність системності дій та невирішеність ряду питань, що стосуються розробки ефективних програм забезпечення надійності авіаційної техніки.

Виконане дослідження може бути використане для обґрунтування шляхів удосконалення системи забезпечення, підтримання та підтвердження льотної придатності повітряних суден цивільної авіації України, а також для усунення недоліків існуючій систем моніторингу стану надійності та безпеки польотів авіакомпаній України.

Ключові слова: цивільна авіація, авіакомпанія, авіаперевезення, повітряне судно, льотна придатність, надійність, безпека польотів.

\section{Вступ}

Цивільна авіація - один із найбільш важливих елементів транспортної інфраструктури будь-якої держави. Ї̈̈ розвиток $\epsilon$ пріоритетним напрямком розвитку усієї транспортної системи країни. В той же час розвиток цивільної авіації пов'язаний із загальними тенденціями міжнародного повітряного транспорту і обумовлений як загальносвітовими, так і внутрішньодержавними соціально-економічними, політичними та іншими факторами.

Аналіз стану розвитку світової авіаційно-транспортної системи свідчить про, в цілому, стабільне зростання об’ємів авіаперевезень в усьому світі й в Україні зокрема. Останнє певною мірою підтверджується даними Державної служби 
статистики України, які представлені на рис.1. Певний провал в 2014-2016 рр. по показниках, що характеризують об'єми авіаційних вантажоперевезень та частково пасажирських перевезень, можна характеризувати як локальний, пов'язаний із різким погіршенням політичних та економічних відносин між Україною та Російською Федерацією, та до яких авіаційно-транспортній системі України вдалося достатньо швидко адаптуватися. Так, вже у 2017 році показники ефективності функціонування системи по обсягу вантажних перевезень вдалося відновити до рівня 2013 року, а по показникам пасажирських перевезень - значно перевищити показники 2013 року.

Темпи відновлення спроможностей авіаційно-транспортної системи України дозволяють говорити про перевищення самих оптимістичних прогнозів, які викладені, наприклад, в аналітичній записці [1]. Однак подальший розвиток системи можливий у випадку максимального усунення (локалізації) стримуючих цей процес фракторів, які діють, як всередині системи, так і поза їі межами.

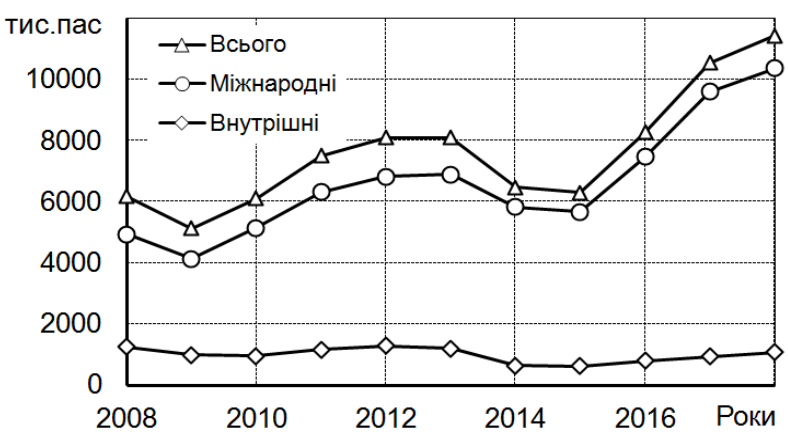

a)

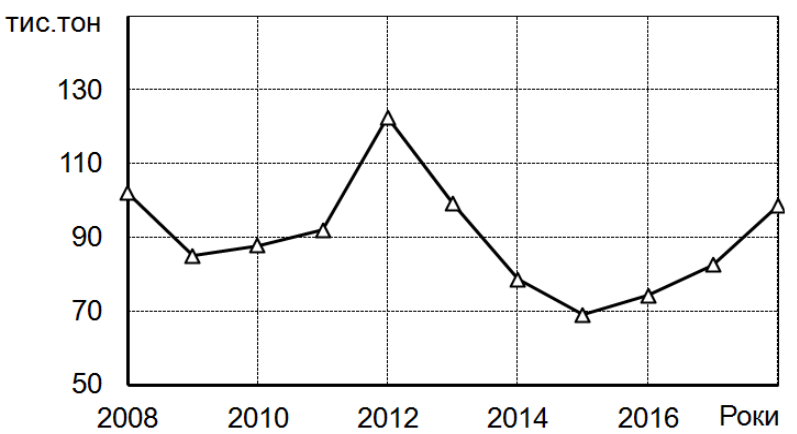

б)

Рис. 1. Тенденції зміни обсягів а) пасажирських перевезень та б) перевезень вантажів авіацією України за період 2003-2017 рр.

\section{Мета роботи}

Для обґрунтування напрямків удосконалення авіаційно-транспортної системи України, як в плані технічного, так і нормативно-правового забезпечення ії функціонування, необхідно мати чітке уявлення про стан авіаційного парку цивільних повітряних суден (ПС), його структуру та проблеми забезпечення льотної придатності.

Слід відмітити, що в даний час авіаційно-транспортна система України володіє певною стаціонарністю. Суттєвих змін, як в плані структури, так і в плані режимів їі функціонування в найближчий час не передбачається. Таким чином, прийшов час звернути увагу на проблеми, які накопичились за увесь період їі формування. У зв'язку із цим метою роботи $€$ виконання докладного аналізу авіаційного парку України, як основи авіаційно-транспортної системи, його структури, технічного стану, а також виявлення проблем, які безпосередньо впливають на стан його льотної придатності.

\section{Основний матеріал статті}

Загальна характеристика парку цивільних повітряних суден України

Станом на 17.12.2018 року в Україні зареєстровано та здійснюють свою комерційну діяльність 69 авіаційних компаній та підприємств, які мають діючі сертифікати експлуатанта ПС [2]. Цими авіакомпаніями та підприємствами 
активно експлуатується, за даними Державної авіаційної служби України, 401 повітряне судно. Всього згідно із реєстром цивільних повітряних суден України (Civil Aircraft Register of Ukraine) за авіакомпаніями, авіапідприємствами та приватними особами обліковано 864 повітряних суден (більше 190 типів ПС та їх модифікацій).

Характеризуючи авіаційну транспортну систему України в цілому слід зауважити, що основною статтею доходу тут, як і раніше, $€$ здійснення пасажирських та вантажних авіаперевезень. В цьому напрямку на авіаринку України працює близько трьох десятків вітчизняних авіакомпаній, 21 з яких здійснюють пасажирські перевезення [2].

Лідируюче місце серед вказаних компаній займають авіакомпанії «Міжнародні авіалінії України», «Роза вітрів», «Азур Ейр Україна», «ЯнЕір» та авіакомпанія «Браво». За підсумками 2018 року цими авіакомпаніями перевезено 11620,6 тис.пасажирів, що складає близько 93\% від усіх пасажирських перевезень в Україні.

Більше половини $(54,2 \%)$ всіх пасажирських перевезень вітчизняних авіакомпаній складають міжнародні регулярні перевезення. У 2018 році відповідно до затвердженого розкладу руху регулярні міжнародні польоти здійснювали 10 вітчизняних авіакомпаній до 46 країн світу, кількість пасажирів, що скористались послугами українських авіаперевізників склала 6796,2 тис. осіб, що складає близько 86\% усіх пасажирів регулярних авіаліній. Упродовж року українськими авіаперевізниками відкрито 17 нових міжнародних маршрутів.

У 2017-2018 рр. значне зростання спостерігалось в такому секторі ринку пасажирських авіаперевезень, як міжнародні польоти на нерегулярній основі. За звітний період 16-ма українськими авіакомпаніями перевезено відповідно 3788,1 та 4649,9 тис. пасажирів. При цьому, близько 85\% таких перевезень було здійснено п'ятьма вищезгаданими авіакомпаніями - лідерами.

На фроні суттєвого зростання за останні роки міжнародних авіаперевезень дуже скромно виглядає обсяг внутрішніх перевезень, який сьогодні не перевищує 10\% від обсягів міжнародних пасажироперевезень і складав у 2018 році 1071,4 тис.пас. Характерними рисами цих перевезень $€$ їх низька привабливість для авіакомпаній та, як наслідок, відсутність конкуренції між ними. Так, внутрішні пасажирські перевезення на регулярній основі у 2018 році виконували усього чотири вітчизняні авіакомпанії за 10 повітряними маршрутами.

Стосовно перевезення вантажів та пошти, то у цьому секторі авіаційних перевезень у 2018 році зафріксована активна діяльність 22 вітчизняних авіакомпаній. Лідерами тут є АТП ДП «Антонов», авіакомпанії «Міжнародні авіалінії України», «Максімус Еірлайнс» Більшу частину вантажоперевезень традиційно складали чартерні рейси в інших державах в рамках гуманітарних та миротворчих програм ООН, а також згідно з контрактами та угодами з іншими замовниками. Вказаними авіакомпаніями, за даними [2], у 2018 році виконано близько 78\% від вказаних перевезень.

В Україні на даний час функціонують і обслуговують комерційні рейси вітчизняних та іноземних авіакомпаній 20 аеропортів та аеродромів. Пасажиропоток через аеропорти України у 2018 році перевищив 20-мільонний рубіж. Кількість відправлених та прибулих повітряних суден перевищувало 182,8 тисяч одиниць. 
В рамках виконання плану наукової та науково-технічної діяльності кафедри 103 Харківського національного аерокосмічного університету імені М.Є. Жуковського було проаналізовано парки 28 авіакомпаній та авіапідприємств України, у складі яких налічується 243 ПС для здійснення вантажних та пасажирських перевезень, як іноземного, так і вітчизняного (в тому числі СРСР) виробництва. Кидається в очі чітко виражена спеціалізація відповідних ПС. Для виконання пасажирських перевезень використовуються переважно ПС іноземного виробництва: Boeing, Airbus, Embraer, DC та деякі інші. Що ж стосується перевезень вантажів та пошти, то тут перевага на боці вітчизняних транспортних літаків та вертольотів. Це, в першу чергу, літаки ДП «Антонова», а також транспортні літаки виробництва «Авіаційного комплексу імені С.В.Ілюшина». Їх частка в авіаційному парку вказаних компаній складає близько 24 та $7 \%$ відповідно.

Згідно із реєстром цивільних повітряних суден України в шести із проаналізованих авіакомпаній експлуатується 53 вертольоти Мі-8 різних модифікацій (близько 21,8\% ПС проаналізованого авіаційного парку) та 9 вертольотів типу Ка-32 (3,7\% ПС проаналізованого авіаційного парку). Основними авіакомпаніями, що здійснюють вертольотні авіаційні перевезення, як в середині країни, так і поза ії межами, є: авіакомпанія «Українські вертольоти», ТОВ «Авіаційно-транспортне агентство «Крунк», ТОВ «Ейр Таурус» та ТОВ «Авіакомпанія «Росьавіа». Це приблизно 92\% усього парку вертольотів даного типу.

Також важливим для аналізу є те, що більшість ПС проаналізованого авіаційного парку не $є$ власністю вітчизняних авіакомпаній та мають реєстрацію поза межами України. Фактично в Україні власні авіапарки, всього 57 із 243 ПС, мають наступні авіакомпанії та авіапідприємства: ПАТ «Мотор Січ», ДП «Антонов», Міжнародна акціонерна авіаційна компанія «Урга», ДАП «Україна». Що ж стосується авіакомпанії "Українські вертольоти», то власником 27 вертольотів цієї компанії згідно реєстру є Міністерство оборони та Національна гвардія України.

\section{Віковий стан авіапарку цивільних ПС України}

3 метою визначення реального вікового стану авіаційного парку цивільних ПС України авторами статті була докладно проаналізована інформація, що розміщена у відкритому доступі на сайті Державної авіаційної служби України. Загалом був проаналізований віковий склад усіх ПС, що зареєстровані в Україні, а також віковий склад повітряних суден найбільших авіакомпаній України.

В результаті проведеного аналізу були отримані відповідні залежності та діаграми, які в повній мірі відображають реальний стан справ із віковим складом парку.

Так, на рис.2 представлено діаграму, на якій наведено розподіл цивільних ПС, що знаходяться сьогодні в експлуатації в провідних авіакомпаніях України, за віком. Аналізуючи її слід відмітити значну нерівномірність даного розподілу та можливість чіткого виділення двох характерних вікових груп авіаційної техніки, які відповідають різним умовам комплектування авіаційного парку цивільних повітряних суден України.

До першої групи, це $\approx 67 \%$ усіх проаналізованих ПС, відноситься авіаційна техніка, вік якої перевищує 25 років. Це техніка в більшості своїй 
виробництва СРСР та України. Частка ж іноземної техніки тут незначна й не перевищує 10\% ПС цієї групи.

До другої вікової групи, правий розподіл на рис.2 відносяться ПС переважно іноземного виробництва. Частка вітчизняної техніки тут незначна та складає близько 9\% (всього 11 ПС).

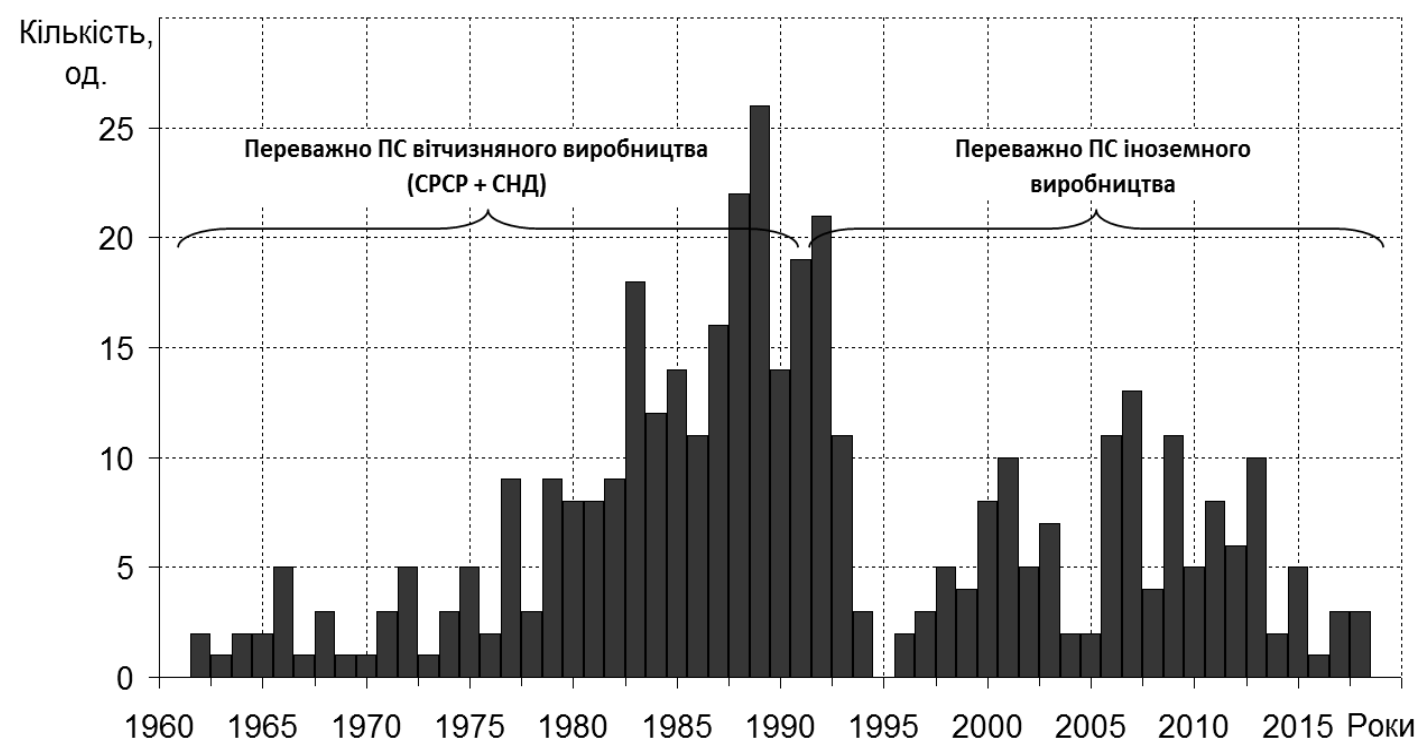

Рис.2 Особливості вікового розподілу вітчизняного авіаційного парку цивільних ПС

Переважна більшість ПС іноземного виробництва сконцентрована в таких авіакомпаніях, як: ПрАТ «Авіакомпанія «Міжнародні авіалінії України»(МАУ), ТОВ «Авіаційна компанія «Роза вітрів», ТОВ «ЯнЕір» ЛТД, ТОВ «Авіакомпанія «Азур Ейр Україна», ТОВ «Авіакомпанія Браво» та інших. Загалом, у перерахованих авіакомпаніях налічується 73 ПС типу Boeing, Airbus, Embraer, Hawker, DC-9, що становить $70 \%$ усіх літаків іноземного виробництва, які зареєстровані та експлуатуються в Україні.

Найбільшими із українських авіакомпаній є ПрАТ «Авіакомпанія «Міжнародні авіалінії України» та ТОВ «Авіаційна компанія «Роза вітрів». Її парк нараховує 47 літаків. Склад та вікова характеристика парку авіакомпанії представлена на рис.3 та 4 відповідно.

Найбільш старими ПС авіакомпанії є Boeing 737-500 та Boeing 767-300. Ïx середній вік становить 25-27 років. Найбільш молодими в авіакомпанії є літаки типу Boeing 737-900ER та Embraer ERJ190-100 LR/STD вік яких становить від 5 до 9 років. В 2016-2018 рр. авіакомпанією було придбано 6 літаків типу Boeing 737-300 (2016 рік - 1 ПС, 2017 рік - 2 ПС та 2018 рік - 3 ПС). Завдяки своєчасній закупівлі нової техніки компанії вдається підтримувати середній вік свого авіаційного парку на рівні $\approx 12$ років.

Підтвердженням сказаному $є$ той факт, що авіакомпанія задекларувала виведення із експлуатації трьох застарілих літаків Boeing 737 Classic, до кінця 2018 року.

Другою за кількісним складом авіаційного парку $є$ авіакомпанія ТОВ «Авіаційна компанія «Роза вітрів». 


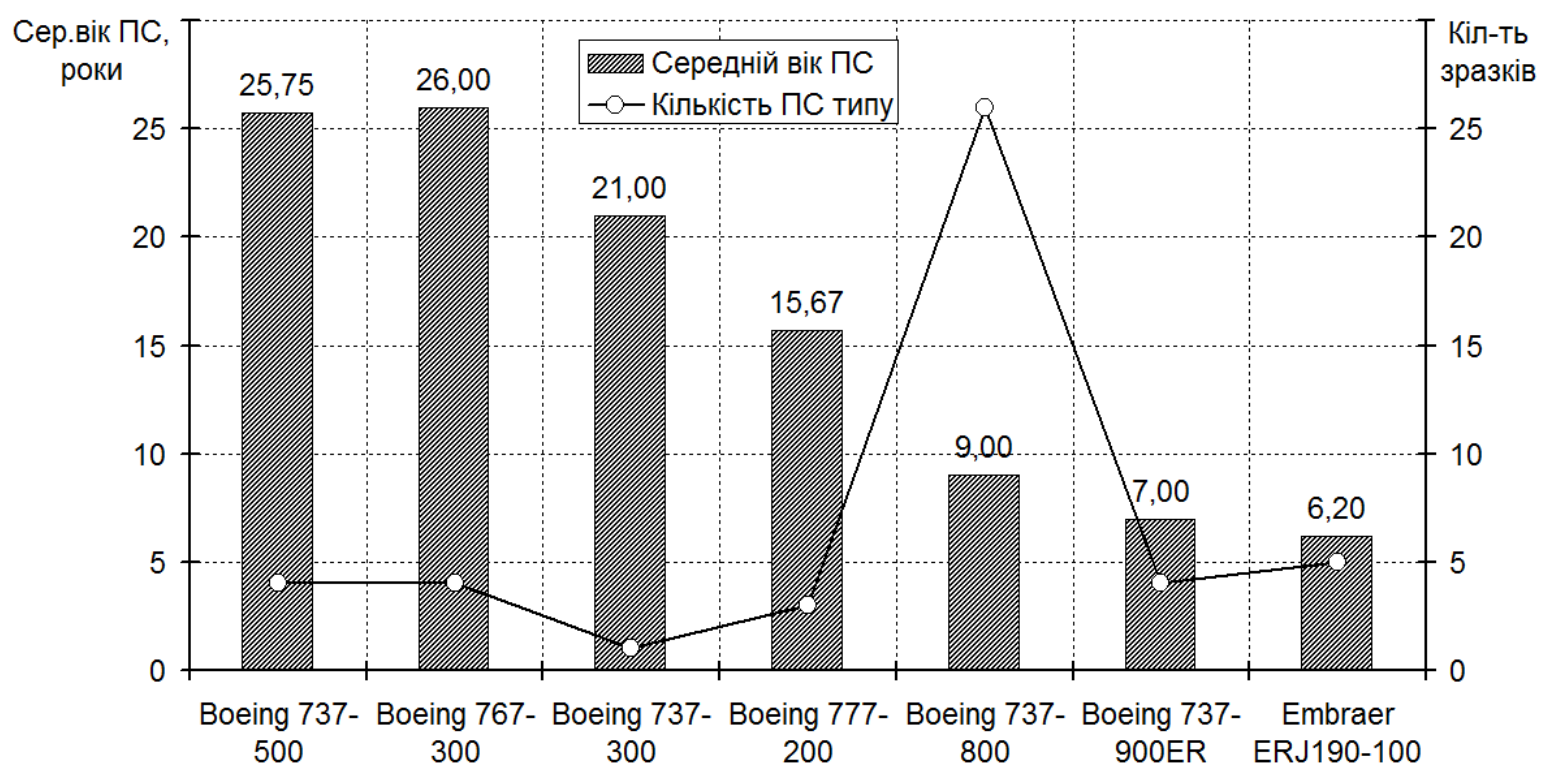

Рис. 3. Віковий та кількісний склад авіаційного парку ПрАТ «Авіакомпанія «МАУ»

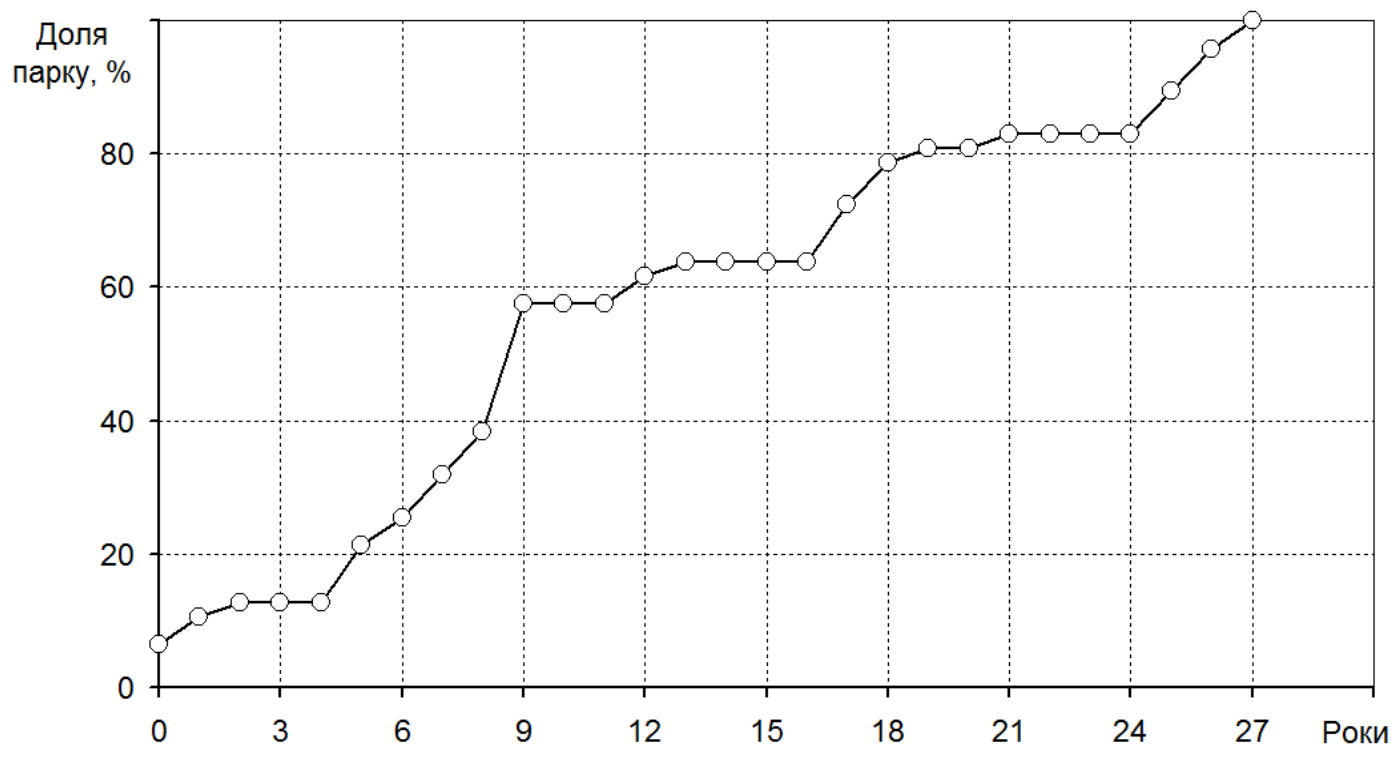

Рис.4. Розподіл ПС парку

ПрАТ «Авіакомпанія «Міжнародні авіалінії України» за віком

Парк ПС цієї компанії складають ПС Airbus різних модифікацій та ПС типу Embraer - 145 EP/EU та LR, які раніше використовувалися компанією «Днеправиа». Компанії також належать три ПС типу Hawker 800XP/850XP. Всього компанії належить 16 ПС.

Літаки типу Airbus 320/321 використовуються авіакомпанією для виконання чартерних рейсів. Для виконання регулярних рейсів використовуються ПС типу Embraer - 145 EP/EU та LR, а також ПС типу Hawker 800XP/850XP.

Середній вік авіаційного парку компанії складає 16,38 років.

Самим старим ПС авіакомпанії є літак Airbus A320-212 1996 року випуску, самими молодими - літаки Airbus A321-231 та Hawker 800XP/850XP 2006 та 
2007 років випуску відповідно. Характеристика складу та середній вік ПС за типами представлено на рис.5.

Аналізуючи рис. 6, на якому представлений розподіл авіаційного парку компанії ТОВ «Авіаційна компанія «Роза вітрів» за віком, можна бачити, що $50 \%$ авіаційного парку складають ПС, вік яких не перевищує 16 років, близько $80 \%-$ вік яких не перевищує 19 років. На долю ж літаків, вік яких становить 20 та більше років, припадає менше 10\% авіаційного парку авіакомпанії.

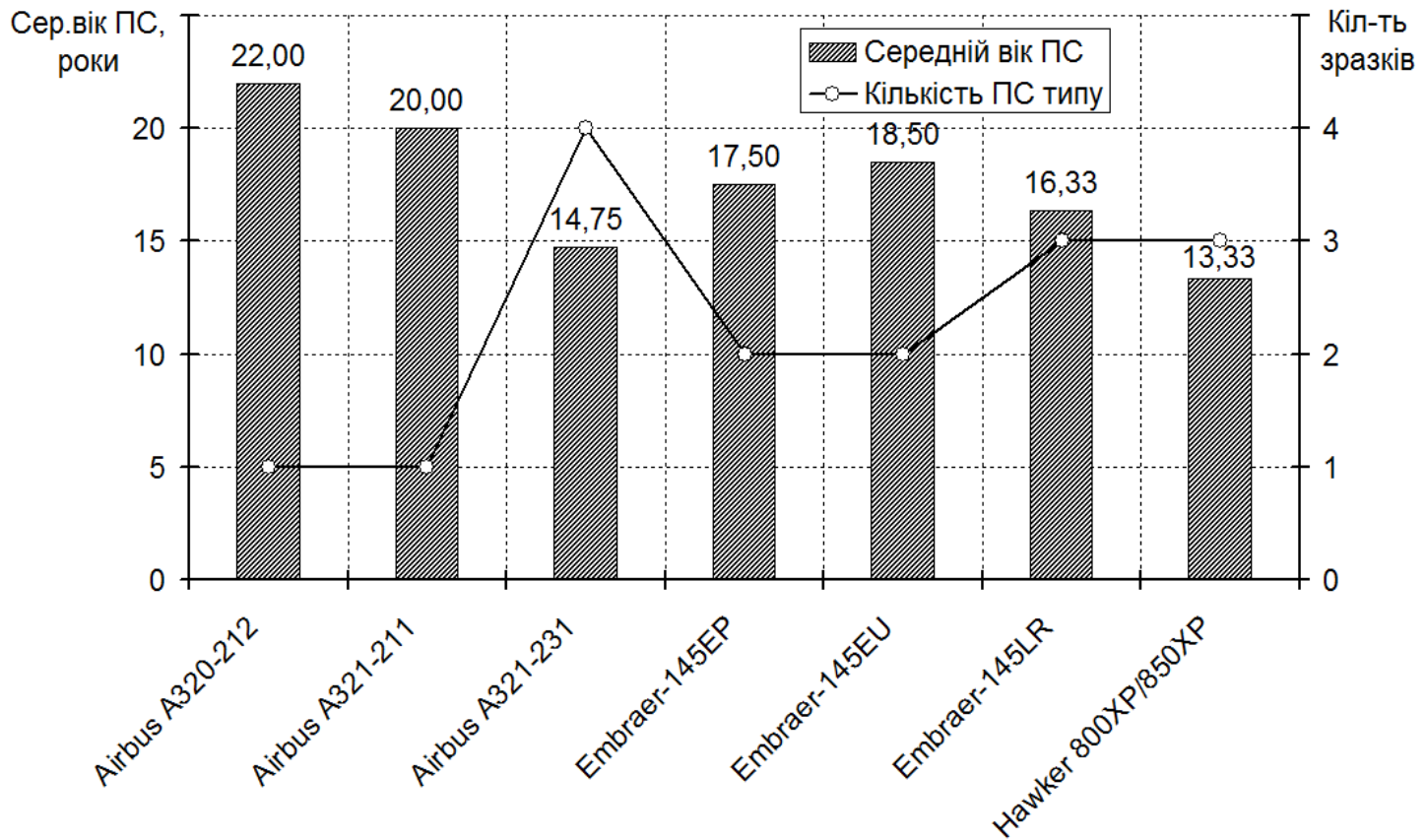

Рис. 5. Віковий та кількісний склад авіаційного парку ТОВ «Авіаційна компанія «Роза вітрів»

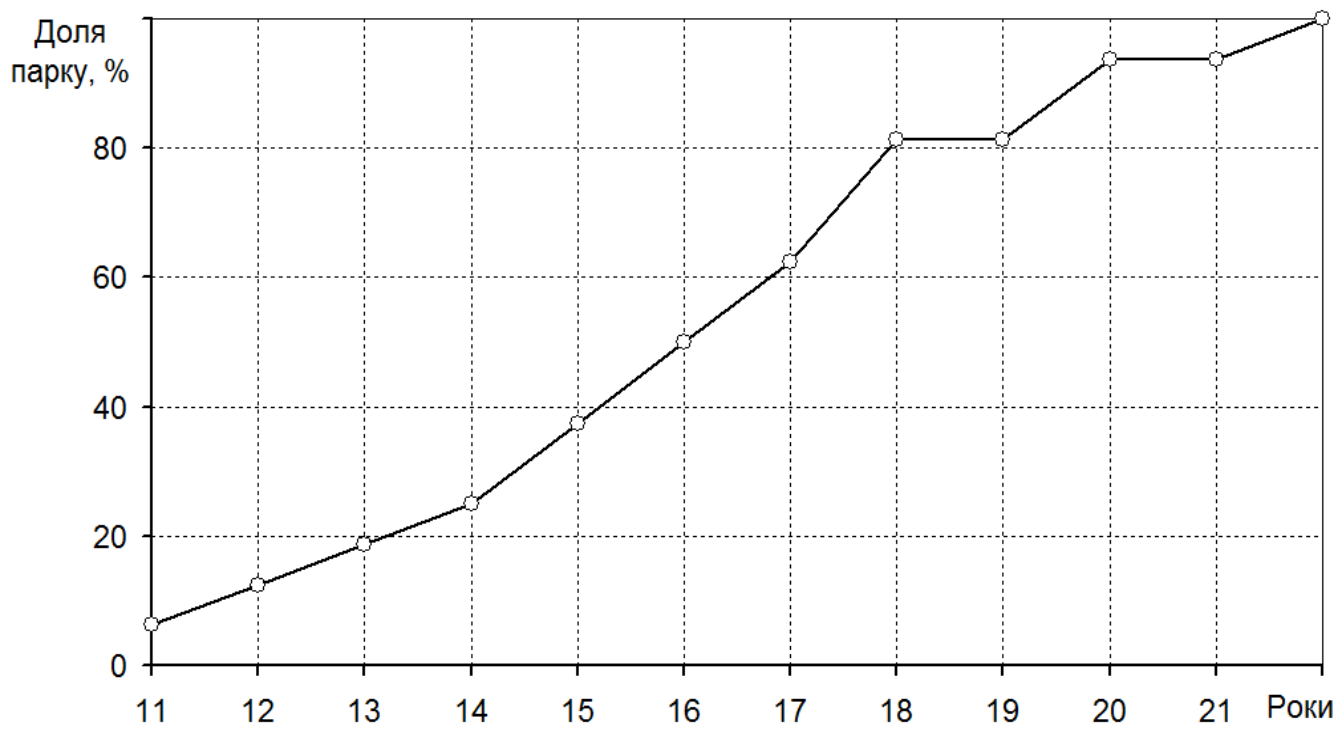

Рис. 6. Розподіл ПС парку ТОВ «Авіаційна компанія «Роза вітрів»за віком

Інформація щодо структури та вікового складу інших авіакомпаній України, на оснащенні яких знаходиться авіаційна техніка іноземного виробництва, 
представлена в таблиці 1 . Тут стан справ дещо інший ніж у ПрАТ «Авіакомпанія «Міжнародні авіалінії України» та ТОВ «Авіаційна компанія «Роза вітрів». Лише $30 \%$ ПС цих компаній мають вік, що не перевищує 20 років. Причиною, очевидно, $є$ відсутність певного матеріального ресурсу для закупівлі нової техніки чи техніки на вторинному ринку із прийнятними ресурсними показниками.

Дійсно, більшість із наведених в таблиці компаній володіють досить скромними авіаційними парками, кількість ПС в яких становить 2-5 одиниць, що 3 урахуванням усіх витрат не дозволяє їм накопичувати та оперувати коштами, які $€$ необхідними для своєчасного оновлення своїх авіаційних парків.

Таблиця 1

Характеристика парку іноземних ПС деяких авіаперевізників України

\begin{tabular}{|c|c|c|c|}
\hline Авіакомпанія & Тип ПС & $\begin{array}{c}\text { Кількість } \\
\text { ПС }\end{array}$ & $\begin{array}{c}\text { Середній вік парку } \\
\text { за типами }\end{array}$ \\
\hline СкайАп & Boeing 737-800 & 3 & 5 \\
\hline \multirow[t]{2}{*}{ Атласджет Україна } & Airbus A320-214 & 1 & 18 \\
\hline & Airbus 320-232 & 1 & 17 \\
\hline \multirow[t]{3}{*}{ Азур Ейр Україна } & Boeing 737-800 & 2 & 17 \\
\hline & Boeing 767-300 & 2 & 26 \\
\hline & Boeing 737-900ER & 1 & 11 \\
\hline \multirow[t]{3}{*}{ Bravo Airways } & Boeing 737-500 & 2 & 27 \\
\hline & DC-9-83 (MD-83) & 2 & 27 \\
\hline & DC-9-82 (MD-82) & 1 & 28 \\
\hline \multirow[t]{2}{*}{ Anda Air } & DC-9-83 (MD-83) & 2 & 28 \\
\hline & Airbus 319-114 & 1 & 22 \\
\hline Дрім Вінд & Боїнг 737-300 & 2 & 27,5 \\
\hline ПрАТ "Авіакомпанія "Буковина" & DC-9-82 (MD-82) & 3 & 28 \\
\hline \multirow[t]{4}{*}{ ТОВ "ЯнЕір" ЛТД } & Боїнг 737-300 & 2 & 28 \\
\hline & Боїнг 737-400 & 3 & 28,67 \\
\hline & Airbus A320-212 & 1 & 21 \\
\hline & Airbus 321-112 & 1 & 20 \\
\hline Всього & - & 30 & 22,8 \\
\hline
\end{tabular}

Так, за даними ресурсу aeronautica.online вартість нового літака типу Boeing 737-800 станом на початок 2018 року становила 102,2 млн.долл. США, a Airbus 321 - 118,3млн.долл. В той же час, на вторинному ринку ці ПС можна придбати набагато дешевше. Так, вартість того ж Boeing 737-800 1998 року виробництва за даними агенства Morten Beyer \& Agnew складає в середньому 13,36 млн.долл. США, a Airbus 321-200 1997 року виробництва - 12,81 млн.долл. Якщо говорити про літаки фрірми McDonnell Douglas типу DC-9-82 та DC-9-83, то їх поточна риночна ціна може не перевищувати 500 - 700 тис.долл.США.

Говорячи про вітчизняну авіаційну техніку, яка експлуатується авіакомпаніями України, то, як можна бачити із матеріалів таблиці 2, вона представлена зразками ПС із фрактичними термінами служби від 16 до 56 років. При цьому середній вік парку складає 33,4 роки. Відносно сучасна техніка представлена літаками Ан-140, Ан-148 та Ан-178, які експлуатуються по одному зразку авіакомпаніями ПАТ «Мотор Січ», ДАП «Україна» та АТП ДП «Антонов» відповідно.

Найбільш старими зразками авіаційної техніки, що активно використовуються українськими авіакомпаніями $€$ літаки типу Ан-12, вік яких 
змінюється в межах від 46 до 56 років. Відносно молодими є літаки типів Ан-74 та Ан -124, середній вік яких становить 25 та 26,6 років відповідно.

Характеристика парку вітчизняних ПС (станом на 12.2018 р.)

\begin{tabular}{|l|l|c|c|c|}
\hline $\begin{array}{c}\text { № } \\
\Pi / \Pi\end{array}$ & \multicolumn{1}{|c|}{ Тип ПС } & Кількість & $\begin{array}{c}\text { Середній вік, } \\
\text { роки }\end{array}$ & $\begin{array}{c}\text { Вікове плече/ } \\
\text { (тіn-тах) роки }\end{array}$ \\
\hline 1. & Ан-12 & 19 & 51 & $10 / 46-56$ \\
\hline 2. & Ан-24 & 3 & 46 & $3 / 45-47$ \\
\hline 3. & Ан-26 & 18 & 36,9 & $11 / 33-44$ \\
\hline 4. & Ан-74 & 4 & 25 & $14 / 17-31$ \\
\hline 5. & Ан-124 & 8 & 26,6 & $17 / 15-32$ \\
\hline 6. & Ан-140 & 1 & 15 & - \\
\hline 7. & Ан-148 & 1 & 7 & - \\
\hline 8. & Ан-178 & 1 & 3 & - \\
\hline 9. & Як-40/42 & 18 & 37,2 & $13 / 30-43$ \\
\hline 10. & Іл-76 & 37 & 29,7 & $14 / 25-39$ \\
\hline 11. & Ми-8 & 8 & 28,5 & $14 / 16-30$ \\
\hline 12. & Ка-32 & 123 & 28,4 & $5 / 26-31$ \\
\hline & Всього & 33,4 & $41 / 15-56$ \\
\hline
\end{tabular}

\section{Стан надійності парку цивільних повітряних суден України та безпеки польотів}

Технічний аспект льотної придатності полягає, в першу чергу, у забезпеченні високої надійності, працездатності і живучості конструкцій ПС при конструюванні та виробництві, а також їх підтриманні при експлуатації ПС в заданих умовах [3]. 3 огляду ж на те, що в авіакомпаніях України більше $60 \%$ авіаційної техніки експлуатується понад 25 років маємо певні проблеми із підтриманням іï льотної придатності. Особливо це стосується техніки виробництва СРСР, яка розроблювалась під вимоги Норм льотної придатності НЛГС-1 (уведені в дію у 1971 році), НЛГС-2 (уведені в дію у 1975 році) та Єдиних норм льотної придатності цивільних транспортних літаків країн - членів Ради економічної взаємодопомоги (уведені в дію у 1985 році).

Згідно із цими вимогами, практично уся вітчизняна техніка, починаючи із 70-х років виробництва і закінчуючи початком 90-х років, на відміну від техніки іноземного виробництва, експлуатується за планово-попереджувальною системою технічного обслуговування та ремонту, яка характеризується цілим рядом недоліків [4], й до того ж є сьогодні достатньо затратною для більшості експлуатантів авіаційної техніки. Саме останнє стало причиною відмови від використання традиційної практики на користь індивідуального підходу. Однак тут також мається ряд проблем, які безпосередньо впливають на стан надійності авіапарку та безпеки польотів.

Фактично, стан надійності авіаційного парку та стан безпеки польотів можуть бути достатньо повно продемонстровані за допомогою залежностей та діаграм, що представлені на рис.7 - 11. Аналізуючи їх можна вказати на наступне:

1. 2012-2016 рр. характеризуються стабільним зростанням 32700 до 10500 годин нальоту на інцидент без суттєвої зміни нальоту на авіаційну подію (АП) та його зниженням до 6400 та 5130 годин у 2017-2018 рр. Тут під інцидентами розуміється сукупність інцидентів (Інц.) та серйозних інцидентів 
(СІ.), що виявлені за даними повідомлень Національного бюро з розслідування АП та інц. з цивільними повітряними суднами України.

Це зменшення має причиною суттєве зростання частки інцидентів, пов'язаних переважно із дією фактору зовнішнього середовища (НЗУ) та фактору людини при практично незмінному нальоті парку. У 2017 році зафріксовано 10 та 8 інцидентів за цими групами факторів в той час як у 2016 році їх кількість була мінімальною за останні 6 років (по одному випадку).

2. Фактичний розподіл кількості інцидентів по групам факторів корелюється із зміною нальоту парку цивільних ПС за роками (рис.7). В той же час настороження викликає суттєва відмінність розподілу інцидентів між групами фракторів, де на перше місце виходить технічний фактор. На його долю припадає близько 38\% усіх облікованих інцидентів. Також занепокоєність викликає велика частка подій, переважно Сl (див. рис.8), причини яких не встановлені. На їх долю припадає близько $25 \%$ К, А та $\mathrm{Cl}$, а також близько $11 \%$ АП та Інц. (див.рис.9). Це свідчить про спробу окремих авіаперевізників приховати причини серйозних інцидентів 3 метою запобігання неприємних (адміністративних, фрінансових, репутаційних та інших) наслідків, як безпосередньо для авіакомпанії, так й для авіаційного персоналу.

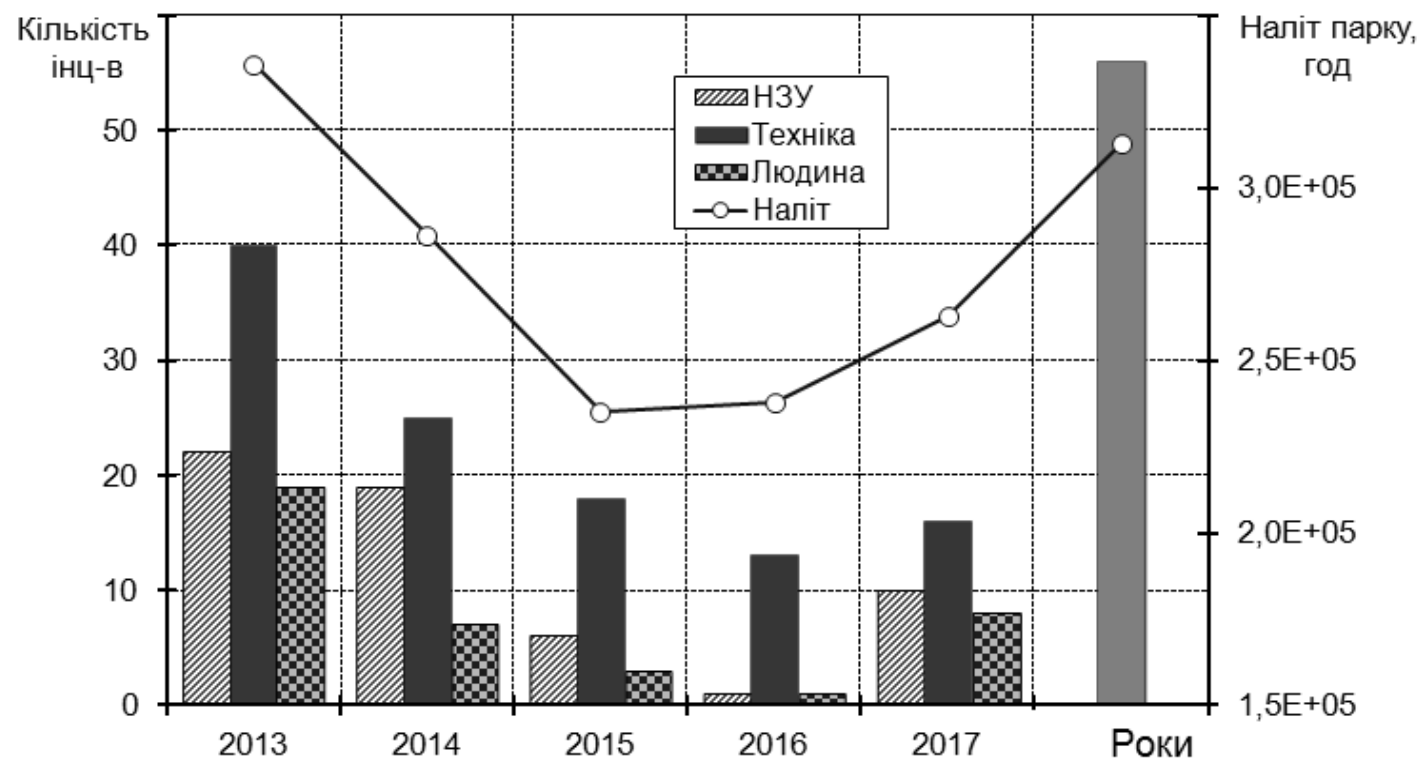

Рис. 7. Розподіл інцидентів за групами фракторів та зміна сумарного нальоту авіаційного парку цивільних ПС у період з 2013 р. по 2017 р.

3. Вікова структура, склад авіаційних парків вітчизняних авіаперевізників $€$ визначальними фракторами при аналізі їх надійності та стану безпеки польотів. На рис.10 представлена залежність, яка отримана в результаті аналізу відповідних показників та даних, які щорічно представляються Сектором аналізу та попередження авіаційних подій Національного бюро 3 розслідування авіаційних подій та інцидентів з цивільними ПС в збірниках [5]. Ця залежність пов'язує віковий стан парків ПС провідних вітчизняних авіакомпаній із таким показником стану безпеки польотів, як кількість інцидентів на $10^{5}$ годин нальоту та характеризується високим рівнем кореляції між ними. Виключенням $\epsilon$ авіакомпанія «Урга», що, на наш погляд, пояснюється як структурою ії авіапарку, який складається із ПС вітчизняного (8 ПС типу Ан-26 різних 
модифікацій) та і іноземного виробництва (7 - SAAB 340B та Cessna 172R), так i авіаційних послуг.

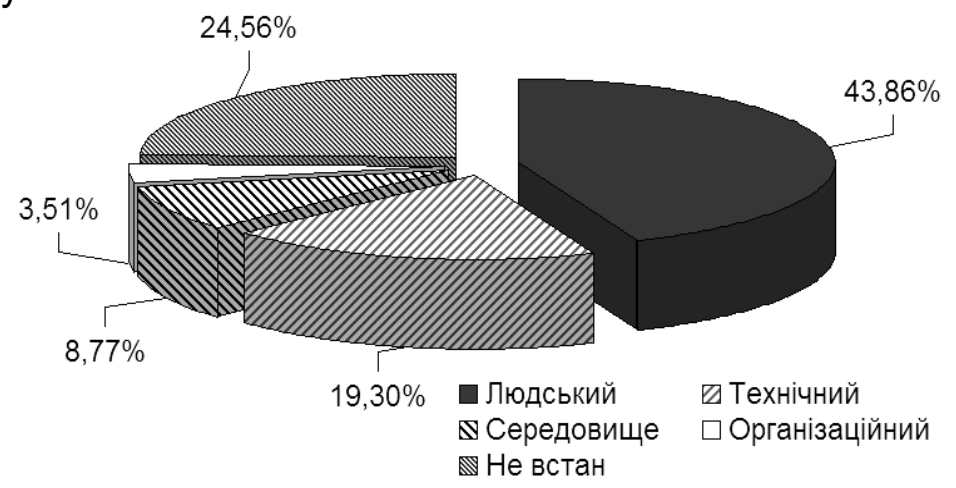

Рис. 8. Розподіл катастрофр (К), аварій (A) та серйозних інцидентів (CI) за групами фракторів

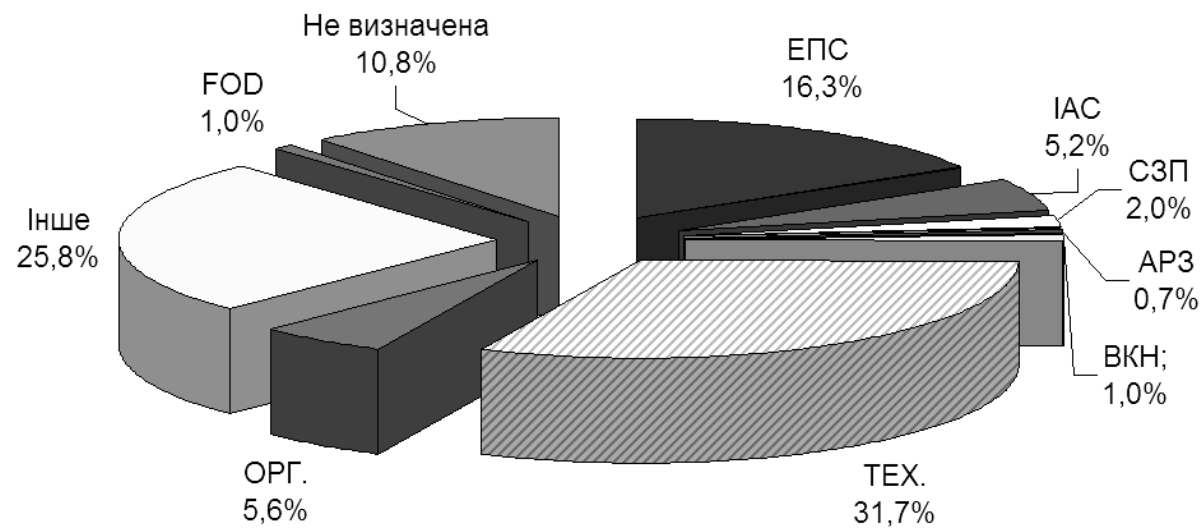

Рис.9. Розподіл усіх подій, що сталися із цивільними ПС України за період 2013-2017рр. за причинами їх виникнення (ЕПС - екіпаж ПС; IAC - інженерно-авіаційна служба; СЗП - персонал служб забезпечення польотів; AP3 - персонал авіаремонтних заводів; ВКН - персонал заводів виробника чи розробника (виробничо-конструктивні недоліки); ТЕХ. - відмови техніки; ОРГ. організаційний фактор; FOD - пошкодження ПС сторонніми предметами; Інше інші причини; Не визнач. - причини події не встановлені)

Звичайно, використаний для аналізу показник $є$ певною мірою комплексним показником, який поряд із технічним фрактором включає людський фрактор та інші фрактори, в тому числі й фрактор навколишнього середовища. В той же час, статистика за 2013-2017 рр. свідчить, що все-таки превалюючим фрактором тут є саме технічний фрактор. Так, на його долю припадає:

для ПС вітчизняного виробництва - 59\% усіх зафріксованих інцидентів;

для ПС іноземного виробництва - 34\% усіх зафіксованих інцидентів.

Доля ж людського фрактора, як для авіакомпаній, які експлуатують ПС іноземного виробництва, так і для авіакомпаній, що експлуатують вітчизняні ПС не перевищує $28 \%$ відповідно.

4. На долю відмов авіаційної техніки за даними офіційної статистики приходиться близько $32 \%$ усіх АП, СІ та Інц (рис.9). На рис.11 наведено розподіл зафріксованих відмов за системами ПС. 


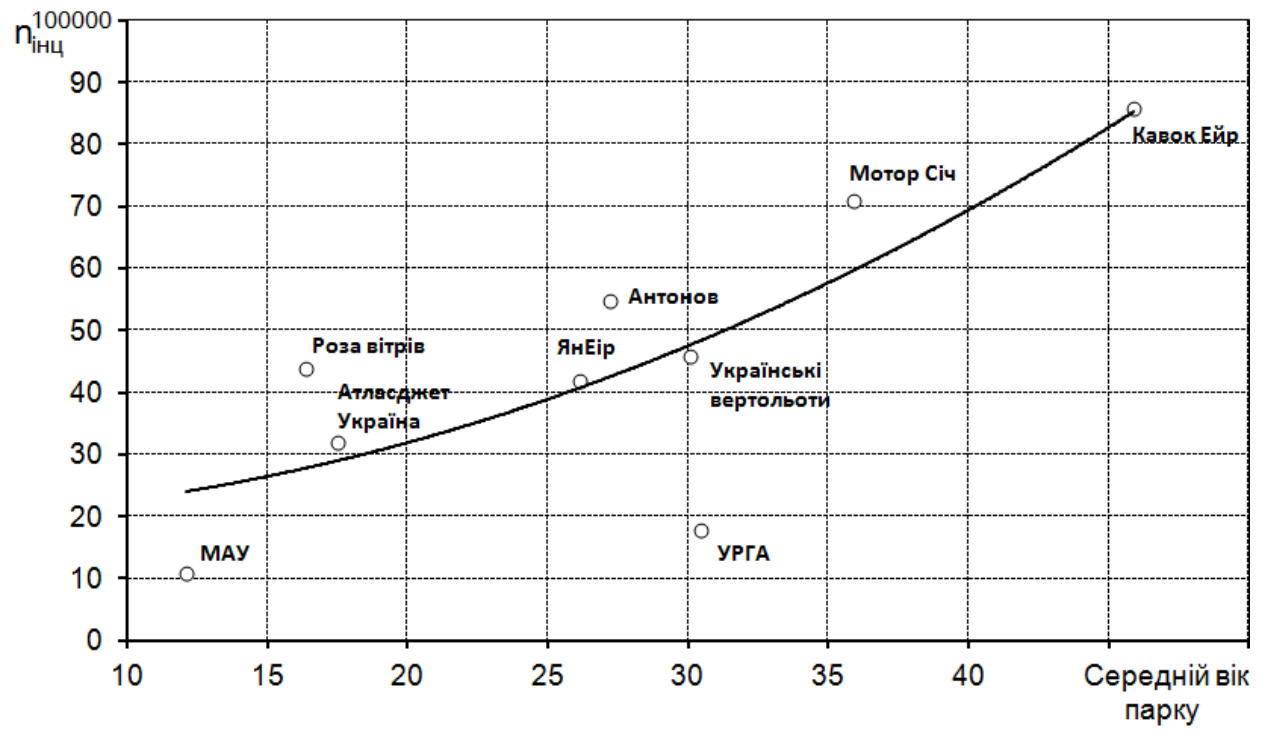

Рисунок 10 - Зв'язок середнього віку авіапарків із безпекою польотів

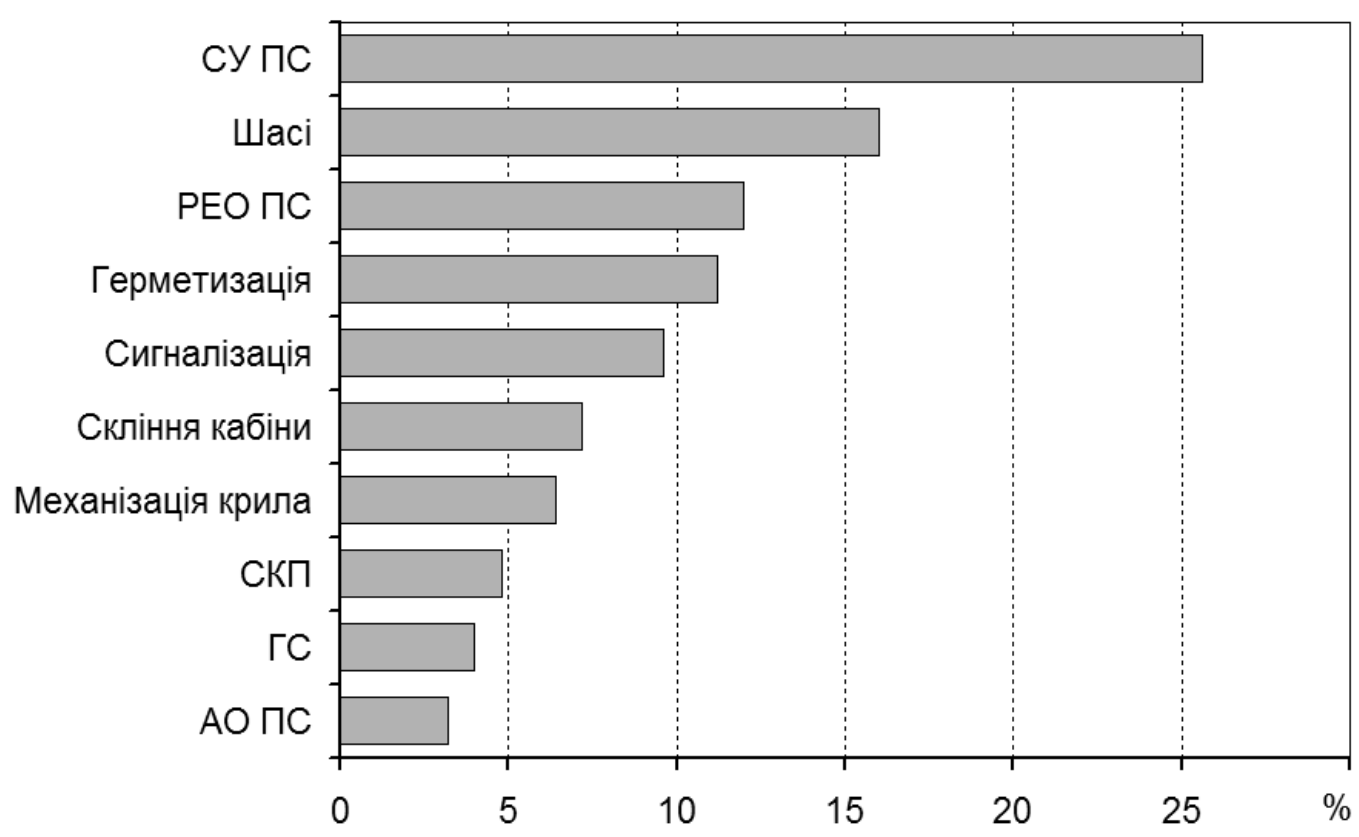

Рис.11. Розподіл усіх зафіксованих за період 2013-2017 рр. відмов за системами ПС

Виходячи із розподілу, основна кількість відмов, близько $75 \%$, належить системам силової установки та системам планера ПС:

- силова установка ПС - 25,6\%;

- шасі - 16\%;

- герметизація кабін та система кондиціювання повітря (СКП) - 16\%;

- скління кабіни екіпажу - 7,2\%;

- механізація крила - 6,4\%;

- гідросистема ПС - 4\%.

На долю радіоелектронного обладнання (РЕО) ПС припадає $12 \%$ усіх відмов, авіаційного обладнання (АО) - 3,2\%. Насторожує велика кількість відмов систем сигналізації правильної роботи систем ПС (сигналізація відкритого 
положення дверей та люків ПС, сигналізація шасі ПС, пожарна сигналізація), що може призводити до проблем у прийнятті рішення екіпажем, виникнення додаткових психофрізіологічних навантажень на екіпаж, а також до порушення алгоритмів CRM. Кількість цих відмов доходить до майже $10 \%$.

5. Порівнюючи статистику по ПС вітчизняного та іноземного виробництва, яка представлена в таблиці 3, можна відмітити значну відмінність у розподілі відмов по окремим системам ПС. Так, очевидною $є$ значна відмінність у кількості зафіксованих відмов по таким системам ПС:

- силова установка ПС.

- герметизація кабін та СКП.

- АО та РЕО ПС.

Говорячи про співвідношення відмов систем і елементів силової установки ПС, їх електричних систем слід відмітити, що причиною вказаної вище відмінності у кількості цих відмов $€$ з великою долею ймовірності відмінність у вікових показниках техніки та відмінності фрактичних умов експлуатації вітчизняної техніки від розрахункових. Слід відмітити, що переважна більшість ПС вітчизняного виробництва та їх силових установок експлуатуються поза межами призначених термінів експлуатації.

Що ж стосується систем герметизації кабін ПС та СКП, то вказана відмінність у кількості відмов може бути пояснена як більшою складністю та вимогливістю до якості ТО цих систем у ПС іноземного виробництва, так і недоліками представлення інформації авіакомпаніям, що експлуатують техніку вітчизняного виробництва. Це ж відноситься й до системи управління механізацією ПС.

Таблиця 3

Розподіл відмов по системам ПС вітчизняного та іноземного виробництва

\begin{tabular}{|l|l|c|c|}
\hline \multirow{2}{*}{$\pi / п$} & \multicolumn{1}{|c|}{ Система ПС } & \multicolumn{2}{|c|}{ Розподіл відмов авіаційної техніки, \% } \\
\cline { 3 - 4 } & & $\begin{array}{c}\text { ПС іноземного } \\
\text { виробництва }\end{array}$ & $\begin{array}{c}\text { ПС вітчизняного } \\
\text { виробництва }\end{array}$ \\
\hline 1. & Силова установка ПС & 18 & 42,8 \\
\hline 2. & Системи шасі & 16,9 & 14,3 \\
\hline 3. & Герметизація кабін та СКП & 21,3 & 2,9 \\
\hline 4. & Скління кабіни екіпажу & 7,9 & 5,7 \\
\hline 5. & Механізація крила & 9,0 & 0,0 \\
\hline 6. & Гідросистема ПС & 4,5 & 2,9 \\
\hline 7. & РЕО ПС & 10,1 & 17,1 \\
\hline 8. & АО ПС & 2,2 & 5,7 \\
\hline 9. & Сигналізація роботи систем ПС & 10,1 & 8,6 \\
\hline & Всього відмов & $\mathbf{1 0 0}$ & $\mathbf{1 0 0}$ \\
\hline
\end{tabular}

\section{Висновки}

Таким чином, враховуючи результати аналізу стану галузі та авіаційного парку цивільних ПС України можна зробити наступні висновки:

1. Сьогодні в Україні сфрормувалась достатньо ефекктивна та розвинута авіаційно-транспортна система, яка характеризується стабільно високими темпами розвитку, високим рівнем адаптивних можливостей до зміни фактичних умов фрункціонування та стійкістю до кризових явищ, які виникають в соціальнополітичному та економічному житті країни. Однак дані успіхи можуть стати 
всього лише локальними без впровадження відповідних заходів щодо їх фріксування та подальшого просування щодо їх покращення на рівні держави.

2. На основі широкого аналізу стану авіапарку України, його діяльності, можна виділити декілька критично важливих, на наш погляд, напрямків забезпечення, й в подальшому успішного розвитку, галузі. Безумовно, головним із них $€$ розвиток вітчизняного авіабудування, основою якого має стати завершення програм створення українських пасажирських та транспортних літаків для заміни застарілих зразків авіатехніки типу Ан-12 та Ан-26, що масово експлуатуються вітчизняними та іноземними авіакомпаніями. Сприяючими фракторами тут є:

- наявність повного циклу створення даних типів ПС в Україні;

- активне застосування авіапідприємствами України сучасних технологій створення ПС. Це насамперед технології CAD/CAM/CAE/PLM, а також міжнародна методика MSG-3 аналізу конструкції и систем ПС при розробці планового технічного обслуговування [6];

- високі досягнуті значення ресурсних показників та перехід до практики т.3. «безремонтної експлуатації», що суттєво знижує вартість життєвого циклу вітчизняної авіатехніки, й робить їі привабливою для використання багатьма українськими та іноземними авіакомпаніями

3. Іншим перспективним напрямком розвитку авіаційної галузі України, особливо із урахуванням зростання ділової активності в регіонах, має стати, на наш погляд, розвиток ринку регіональних авіаперевезень.

Дослідження свідчать про певний вакуум у цій сфрері, що викликано відсутністю реальної державної підтримки тих вітчизняних авіакомпаній, які безпосередньо сьогодні здійснюють внутрішні авіаперевезення. В той же час об'єднання зусиль в цьому напрямку держави та провідних авіакомпаній України спроможне надати суттєвий поштовх вітчизняному авіабудівництву (мова йде про вже згадані проекти створення високоефективних ПС регіонального класу) та забезпечити сталий розвиток авіації загального призначення.

4. Забезпечення ефективності заходів розвитку авіаційної галузі України потребує також вирішення ряду принципових проблем, пов'язаних із забезпеченням просування українського продукту на міжнародному авіаринку та ефективного й безпечного його використання на внутрішньому ринку. До цих проблем відноситься проблема гармонізації вітчизняного законодавства в сфері льотної придатності із законодавством Європейського Союзу, яка на даний час не вирішена в повному обсязі, а це не дозволяє сьогодні говорити про єдині «правила гри» для вітчизняних і іноземних виробників авіаційної техніки та постачальників авіаційних послуг.

5. Аналіз авіаційного парку України, свідчить про наявність у його складі великої кількості застарілої авіаційної техніки вітчизняного виробництва (близько 50\% дослідженого парку), рівень надійності якої постійно знижується. В той же час не слід очікувати, що українські авіаперевізники вже завтра відмовляться від практики використання цієї техніки на користь більш нових зразків, як іноземного, так і вітчизняного виробництва. На думку експертів, це можливо лише у перспективі через 10 - 20 років. У зв'язку із цим потребує особливої уваги, державного втручання та підтримки проблема забезпечення експлуатації застарілого авіаційного парку вітчизняної авіатехніки, як в плані створення якісної нормативно-правової бази, так і в плані методичного забезпечення підтримання високих показників його льотної придатності. 
6. Враховуючи останнє очевидною постає проблема створення та ефрективного фрункціонування єдиної державної системи моніторингу стану надійності авіаційної техніки України та безпеки польотів, що є обов'язковим, у відповідності з р.9 Doc.ICAO 9760 AN/967, елементом системи підтримання льотної придатності ПС. Результати ж досліджень, які наведені в статті, свідчать, що в нашій державі відсутня відповідна культура надання даних. Дані про виявлені відмови, інциденти, серйозні інциденти, їх причини, дані про проблемні питання безпеки польотів до відповідних державних органів не надаються взагалі, або надаються у викривленому вигляді. Результатом цього $€$ неповна та недостовірна інформація, не правильні висновки, не ефективні профрілактичні заходи, що в умовах різкого зниження надійності техніки несе безпосередню загрозу безпеці польотів.

\section{Список літератури}

1. Современное состояние и проблемы развития авиаперевозок в государствах-участниках соглашения о гражданской авиации и использовании воздушного пространства в первой половине 2015 года. Аналитическая записка. - М.: Межгосударственный авиационный комитет, 2015. - 46 с.

2. Статистичні дані в галузі авіатранспорту. Підсумки діяльності авіаційної галузі України за 2018 рік. Офріційний сайт Міністерства інфраструктури України. [Електронний ресурс] / Режим доступу: https://mtu.gov.ua/content/statistichni-daniv-galuzi-aviatransportu.html.

3. Орловский М.Н. Поддержание летной годности воздушных судов / М.Н.Орловский, С.Ш. Шаабдиев - Харьков: НАУ (ХАИ), 2015. - 102 с

4. Чинючин Ю.М. Проблемы мониторинга ресурсных характеристик в задачах поддержания летной годности воздушных судов // Ю.М. Чинючин / Научный Вестник МГТУ ГА. - М.: МГТУ ГА, 2017. - Том 20, №06 - С.6-14.

5. Аналіз стану безпеки польотів за результатами розслідування авіаційних подій та інцидентів з цивільними повітряними суднами України та суднами іноземної реєстрації. - К.: НБРЦА, 2013-2018.

6. Шапкин В. Поддержание летной годности самолетов «Ан» в гражданской авиации России //В. Шапкин, К. Арапьев/ Международный авиационно-космический журнал «АвиаСоюз» $\underline{\text { https://www.aex.ru/fdocs/ }}$ $1 / 2017 / 6 / 7 / 28376$.

\section{Reference}

1. Sovremennoe sostojanie i problemy razvitija aviaperevozok v gosudarstvahuchastnikah soglashenija o grazhdanskoj aviacii i ispol'zovanii vozdushnogo prostranstva $\vee$ pervoj polovine 2015 goda. [The current state and problems of air traffic development in the member states of the agreement on civil aviation and the use of airspace in the first half of 2015]. Analytic note. - M .: The Interstate Aviation Committee, 2015. $-46 \mathrm{p}$.

2. Staty`sty`chni dani v galuzi aviatransportu. Pidsumky` diyal’nosti aviacijnoyi galuzi Ukrayiny' za 2018 rik. [Statistics in the field of air transport. The results of the aviation industry in Ukraine for 2018.] Official site of the Ministry of Infrastructure of Ukraine // https://mtu.gov.ua/content/statistichni-dani-v-galuzi-aviatransportu.html.

3. Orlovskij M.N. Podderzhanie letnoj godnosti vozdushhnih sudov / M.N.Orlovskij, S.Sh. Shaabdiev [Continuing airworthiness of aircraft] - Kharkov: NAU (KhAl), 2015. - 102 p. 
4. Chinjuchin Ju.M. Problemy monitoringa resursnyh harakteristik v zadachah podderzhanija letnoj godnosti vozdushnyh sudov [Problems of monitoring resource characteristics in the maintenance of aircraft airworthiness] // Ju.M. Chinjuchin / The Bulletin of MSTU CA. - M.: MSTU CA, 2017. - Part 20, №06 - p.6-14.

5. Analiz stanu bezpeky` pol`otiv za rezul'tatamy` rozsliduvannya aviacijny`x podij ta incy`dentiv z cy`vil’ny'my` povitryany`my` sudnamy` Ukrayiny` ta sudnamy` inozemnoyi reyestraciyi [Analysis of the state of flight safety based on the results of the investigation of aviation events and incidents with civil aircraft of Ukraine and aircraft of foreign registration]. - K.: National Bureau of Air Accidents Investigation of Ukraine, 2013-2018.

6. Shapkin V. Podderzhanie letnoj godnosti samoletov «An» V grazhdanskoj aviacii Rossii [Continuing airworthiness of aircraft "An" in Russian civil aviation] // V. Shapkin, K. Arap'ev / International Aerospace Magazine «AviaSojuz» https://www.aex.ru/fdocs/ 1/2017/6/7/28376.

Надійшла до редакції 15.03.2019, розглянута на редколегії 18.03.2019.

\section{Investigation of the airworthiness conditions and perspectives development of the civil aviation park of Ukraine}

A survey of the state of the aviation park of Ukraine was conducted: trends of changes in the indicators of efficiency of use of civil aviation of Ukraine during period since 2003 till 2018 were shown, as well as the age and quantity composition of the aviation park of the leading airlines, such as the International Airlines of Ukraine and Aviation Company "Rosa winds "and others.

It is determined that the development of civil aviation is associated with the general tendencies of international air transport and is caused both by global and domestic state social, economic, political and other factors.

It has been established that the issues of aircraft reliability, flight safety, which are directly related to the maintenance and maintenance of airworthiness of aircraft, and will remain relevant to all countries without exception, regardless of the level of development and the state of the technologies used to provide them.

It was established that the main factors determining the relevance of issues of maintaining and confirming the airworthiness of civil aircraft are: the need to ensure the safe operation of different age groups of aircraft at the same time and the use of intensively aging technology of domestic production; insufficient efficiency of the monitoring system on the state of reliability and efficiency of aircraft equipment; unreadiness of the existing system of operation to effective functioning in conditions of mass exhaustion of established terms of service for most objects of aviation engineering; catastrophically low level of funding for research related to the technical support of the operation of aircraft; the lack of systemic action and the unresolved issues in the development of effective programs for ensuring the reliability of aviation technology.

The study can be used to substantiate ways to improve the system of maintenance, maintenance and confirmation of the airworthiness of civil aviation aircraft of Ukraine, as well as to overcome the disadvantages of existing systems of monitoring the reliability and safety of flights of Ukrainian airlines.

Key words: civil aviation, airline, air transportation, aircraft, airworthiness, reliability, flight safety. 


\section{Відомості про авторів:}

Орловський Михайло Миколайович - канд. техн. наук, доцент, доцент кафедри проектування літаків та вертольотів, Національний аерокосмічний університет ім. М.Є. Жуковського «Харківський авіаційний університет», Харків, Україна. orl104@ukr.net. ORCID 0000-0003-3529-1816.

Приймак Андрій Володимирович - канд. техн. наук, доцент, доцент кафедри проектування літаків та вертольотів, Національний аерокосмічний університет ім. М.Є. Жуковського «Харківський авіаційний університет», Харків, Україна. matrix 1971@ukr.net ORCID 0000-0002-4707-2429.

Височанська Юлія Юріївна - асистент кафедри проектування літаків та вертольотів, Національний аерокосмічний університет ім. М.Є. Жуковського «Харківський авіаційний університет», Харків, Україна. y.vysochanskaya@khai.edu ORCID 0000-0002-2659-5669.

Гальчинський Костянтин Анатолійович - доцент кафедри інженерноавіаційного забезпечення інженерно-авіаційного фракультету Харківського національного університету Повітряних Сил ім.І.Кожедуба, Харків, Україна. kostya.678@ukr.net ORCID 0000-0003-4198-9874

About the authors:

Mykhailo Orlovskyi - Ph.D, Associate Professor, Department of Airplanes and Helicopters Design, National Aerospace University, Kharkiv, Ukraine, orl104@ukr.net ORCID 0000-0003-3529-1816.

Priymak Andrey - Ph.D, Associate Professor, Department of Airplanes and Helicopters Design, National Aerospace University, Kharkiv, Ukraine, matrix 1971@ukr.net ORCID 0000-0002-4707-2429.

Vysochanska Yuliya - Assistant, Department of Airplanes and Helicopters Design, National Aerospace University, Kharkiv, Ukraine, y.vysochanskaya@khai.edu ORCID 0000-0002-2659-5669.

Halchinsky Konstantin - Associate Professor, Engineering and Aviation faculty, Ivan Kozhedub Kharkiv National Air Force University, Kharkiv, Ukraine, kostya.678@ukr.net ORCID 0000-0003-4198-9874. 